\title{
Modern Security Equipments Available in Garment Shops in City
}

\author{
Sumathyarjunan, W. Porselvi, S. Janifer Vinnarasi
}

\begin{abstract}
Customer Relationship Management (or CRM) portrays a business $P C$ system for managing its coordinated efforts with its customers. A CRM system is an essential gadget for business today that supports you manage your customers, arrangements and publicizing. The CRM connects with you to manage your new leads from the basic contact through the business pipeline to end. You can set follow up tasks for yourself and partners, and report on the whole of your activities and arrangements checks. The objective is to have a "360 degree see" of the customer, all information about the customer in one spot.
\end{abstract}

Keywords: Customer Relationship Management, banking services.

\section{INTRODUCTION}

Relationship progressing is a piece of client relationship the authorities (CRM) that spotlights on client commitment and entire arrangement client obligation rather than shorter-term objectives like client acquisition and individual plans. The objective of relationship showing (or client relationship advancing) is to make solid, even energized, client association with a brand that can incite propelling business, free verbal movement and data from clients that can make leads. [1]-[5]

\section{A. Client Relationship Management}

Customer relationship the board (CRM) is an approach to manage a connection's joint exertion with present and potential customers. It uses data evaluation about customers' history with a relationship to improve business relationship with customers, unequivocally focusing on customer care in conclusion driving blueprints progress. CRM that sales data from a level of different correspondence stations, including a connection's website, telephone, email, live talk, propelling materials, and much furthermore starting

late, online life. Through the CRM approach and the structures used to empower it, affiliations become acquainted with their masterminded intrigue social events and how to best consider their needs.

Revised Manuscript Received on December 30, 2019.

Sumathyarjunan, , Assistant Professor, Department Of Science and Humanities,Bharath Institution Of Higher Education And Research Tamil Nadu,India.Email: sumi.renu@gmail.com

WPorselvi,, Assistant Professor, Department Of Science and Humanities,Bharath Institution Of Higher Education And Research Tamil Nadu,India.Email porselviwilson@gmail.com Humanities,Bharath Institution Of Higher Education And Research Tamil Nadu,India.Email: mjjaa24@gmail.com
One critical part of the CRM approach is the systems of

S. Janifer Vinnarasi Assistant Professor, Department Of Science and

Information followed in a CRM structure may join contacts, potential clients, clients, measurement or firmographic data, bargains history, particular assistance and organization sales, and anything is possible from that point. CRM systems can similarly automate many promoting, arrangements and support structures, helping associations give an anticipated experience to customers and potential outcomes, while moreover cutting down their costs.[6]-[10]

\section{REVIEW OF LITERATURE}

\section{PRINCIPLES OF CRM}

The fundamental basic standards controlling advancement of CRM can be outlined as:

1. Guideline of 'Client Life Time Value (CLV)'

2. Guideline of 'Consumer loyalty (CS)'

3. Guideline of 'Client Loyalty'

4. Guideline of 'Wallet portion of Customer'

5. Guideline of 'Strategically pitching and Up Selling'

6. Guideline of 'Client Profitability'.

\section{SCOPE OF STUDY}

This investigation is centered around the effect of client relationship the executives in a Retail Sector. It is attractive to stretch out as could be expected under the circumstances, however this is beyond the realm of imagination in light of time compels. This investigation is just centered around the retail segment of Big Bazaar, however it just covers one chose region in Chennai at Express Avenue. It encourages the clients to rate the administrations gave by the Retail business.[11]-[15]

\section{OBJECTIVES OF THE STUDY}

1. To know the different CRM practices used in Big Bazaar

2. To find out the satisfaction level of customers with the services of Big Bazaar

Speculation FOR TEST

1. H0: There is no noteworthy connection among Age and in general fulfillment level by CRM

H1: There is a noteworthy connection among Age and in general fulfillment level by CRM [16]-20]

\section{RESULTS AND INTERPRETATION}

Different CRM rehearses which the enormous bazaar use in their outlet Table

Descriptive Statistics

Blue Eyes Intelligence Engineering 


\begin{tabular}{|c|c|c|c|c|c|}
\hline CRM Practices & $\mathrm{N}$ & Minimum & Maximum & Mean & Std. Deviation \\
\hline Online service & 100 & 1 & 5 & 4.22 & .883 \\
\hline Well trained employees & 100 & 2 & 5 & 3.87 & .706 \\
\hline Understanding the customers & 100 & 2 & 5 & 3.85 & .821 \\
\hline Customer self-service & 100 & 1 & 5 & 3.85 & .857 \\
\hline \begin{tabular}{|l} 
Eradicate customer problems \\
\end{tabular} & 100 & 1 & 5 & 3.77 & .908 \\
\hline Updated customer data & 100 & 2 & 5 & 3.74 & .799 \\
\hline Follow up customers & 100 & 1 & 5 & 3.77 & 1.081 \\
\hline $\begin{array}{l}\text { Immediate customer } \\
\text { Response }\end{array}$ & 100 & 2 & 5 & 3.89 & .803 \\
\hline Customer Profitability & 100 & 2 & 5 & 3.73 & .763 \\
\hline Customer interaction & 100 & 1 & 5 & 3.61 & .863 \\
\hline Valid N (list wise) & 100 & & & & \\
\hline
\end{tabular}

\section{A. Interpretation}

From the above table is clear that the most of the respondent's choice was online service which the Big bazaar uses in their outlet. Statistically the mean value for the online service is highest that is 4.22 . The next highest value is 3.89 that it says that there were immediate customer response, and the next factor has a highest mean value of 3.87 , where the employees were well trained.

\section{B. Hypothesis Testing}

H0: There is no significant relationship between Age and overall satisfaction level

H1: There is a significant relationship between Age and overall satisfaction level

\section{ANOVA}

\begin{tabular}{|c|c|c|c|c|c|c|}
\hline & & $\begin{array}{l}\text { Sum of } \\
\text { Squares }\end{array}$ & $\mathrm{df}$ & $\begin{array}{l}\text { Mean } \\
\text { Square }\end{array}$ & F & Sig. \\
\hline \multirow{3}{*}{$\begin{array}{l}\text { Customer } \\
\text { service }\end{array}$} & \begin{tabular}{|l|} 
Between \\
Groups
\end{tabular} & 5.609 & 3 & 1.870 & 3.617 & .016 \\
\hline & Within Groups & 49.631 & 96 & \begin{tabular}{c|c|}
.517 \\
\end{tabular} & & \\
\hline & \begin{tabular}{|l|} 
Total \\
\end{tabular} & 55.240 & 99 & & & \\
\hline \multirow{3}{*}{ Online service } & \begin{tabular}{|l|} 
Between \\
Groups
\end{tabular} & 5.141 & 3 & 1.714 & 4.375 & .006 \\
\hline & Within Groups & 37.609 & 96 & .392 & & \\
\hline & \begin{tabular}{|l|} 
Total \\
\end{tabular} & 42.750 & 99 & & & \\
\hline \multirow{3}{*}{ Parking service } & $\begin{array}{l}\text { Between } \\
\text { Groups }\end{array}$ & 1.947 & 3 & .649 & .898 & .445 \\
\hline & Within Groups & 69.363 & 96 & .723 & & \\
\hline & \begin{tabular}{|l} 
Total \\
\end{tabular} & 71.310 & 99 & & & \\
\hline \multirow{3}{*}{ Billing sevice. } & $\begin{array}{l}\text { Between } \\
\text { Groups }\end{array}$ & .311 & 3 & .104 & .113 & .952 \\
\hline & Within Groups & 87.929 & 96 & .916 & & \\
\hline & \begin{tabular}{|l} 
Total \\
\end{tabular} & 88.240 & 99 & & & \\
\hline \multirow{3}{*}{ Delivery service } & $\begin{array}{l}\text { Between } \\
\text { Groups }\end{array}$ & .057 & 3 & .019 & .020 & .996 \\
\hline & Within Groups & 91.943 & 96 & .958 & & \\
\hline & \begin{tabular}{|l|} 
Total \\
\end{tabular} & 92.000 & 99 & & & \\
\hline
\end{tabular}

since, the significant value for the satisfaction of customer service is 0.16 less than the significant level therefore the hypothesis is accepted, hence it can be concluded that there is a significant relationship between the age and overall satisfaction in terms of customer service. the next factor is the online service whose significant value is 0.006 which is less than the significant level therefore the hypothesis is accepted, hence it can be concluded that there is a significant relationship between the age and overall satisfaction in terms of online service. the following are the findings of the study:majority of the respondents belong to the age category of $18-22$ i.e. $50 \%$ most of the respondents are female which is about $67 \%$ nearly $56 \%$ of the respondents are undergraduate. majority of the respondents are self-employed that is $65 \%$ the most of the respondent's annual income is less than 1 lakh.

the most important ways through which the customers are retained by big bazaar are accepting credit cards, attractive advertising, meeting customers' expectations and free offers. most of the respondents are satisfied with the customer service as well as the online services of big bazaar.[20]-[24]

\section{SUGGESTIONS}

- Convert the clients into attention specialists. Build up a motivator for them to inform partners and companions concerning the estimation of your items or administrations. A support from them is more compelling than any measure of promoting - and it is a lot less expensive.

- Surprise your clients with unforeseen worth. In the event that Big Bazaarsell items, incorporate a "not widely known reward" with each request. In the event that Big Bazaarsell administrations, start accomplishing a bonus for each client or customer without charging for it.

- Reward them each time they allude somebody who turns into a client. Their reward can be as straightforward as a credit toward their next request from them.

- Innovative mode of advertising can be used by Big Bazaar to promote their products. [25]

\section{CONCLUSION}

.Tomaintain a legitimate association with the clients was viewed as the principle thought process of Big Bazaar. Yet the administration should concentrate a greater amount of their cons so as to improve client association with the clients. This assists the Big Bazaar the executives with doing all progressions inside them. There is an absence of promoting media inBig Bazaar with the clients which can likewise be mulled over for their development and advancement. The staff administration additionally doesn't meet the desires. A large portion of the staff don't know about the various areas and the items which are accessible under such segments. Consequently the representatives can be all around prepared so this can be a factor to create client relationship. A legitimate client relationship the board can generally make the Management to create themselves regarding their development and furthermore their organization's introduction. 


\section{REFERENCES}

1. Vasanthi, S. \& Rabiyathul Basariya, S. 2019, "Influence of value analysis and cross training in industry", International Journal of Engineering and Advanced Technology, vol. 8, no. 6, pp. 1810-1811.

2. Velvizhi, R., Sri Gowtham, S. \& Jeya Priya, D. 2019, "Examination of early feedbacks for effective product retailing on E-commerce websites", International Journal of Engineering and Advanced Technology, vol. 8, no. 6 Special Issue 2, pp. 703-706.

3. Anuradha, C., Pothumani, S. \& Kavitha, R. 2019, "A novel method towards E-commerce", International Journal of Engineering and Advanced Technology, vol. 8, no. 6 Special Issue 2, pp. 535-538.

4. Thomas, J. \& Rabiyathul Basariya, S. 2019, "A study on the issues of financial ratio analysis", Indian Journal of Public Health Research and Development, vol. 10, no. 3, pp. 1079-1081.

5. Ramachandran, S. \& Rabiyathul Basariya, S. 2019, "Online marketing study on customer satisfaction and relationship", Indian Journal of Public Health Research and Development, vol. 10, no. 3, pp. 1072-1078.

6. Priya, R., Vinothini, G. \& Cor Jesu, C.D. 2019, "The mentor-protégé relationship for professional growth", Journal of Advanced Research in Dynamical and Control Systems, vol. 11, no. 9 Special Issue, pp. 1110-1119.

7. Jannifer Rani, N., Bina Pani, S. \& Nimisha, N.S. 2019, "A study on money back polices available in LIC", Journal of Advanced Research in Dynamical and Control Systems, vol. 11, no. 9 Special Issue, pp. 833-839

8. Saillaja, V., Jhansi Rani, K. \& Catherine, R. 2019, "Global marketing management planning and organization", Journal of Advanced Research in Dynamical and Control Systems, vol. 11, no. 9 Special Issue, pp. 489-493.

9. Saillaja, V., Jhansi Rani, K. \& Catherine, R. 2019, "The new phase of marketing information system", Journal of Advanced Research in Dynamical and Control Systems, vol. 11, no. 9 Special Issue, pp. 482-488.

10. Thoufiqulla \& Raju, D.V. 2019, "Perception of indian investor towards investment in mutual funds with special reference to mip funds", Journal of Advanced Research in Dynamical and Control Systems, vol. 11, no. 5, pp. 177-183.

11. Jasmine, K.R.M. \& Basariya, S.R. 2018, "A study on the customers benefits on mutual funds", International Journal of Civil Engineering and Technology, vol. 9, no. 4, pp. 45-48.

12. Vasanthi, S. \& Basariya, S.R. 2019, "Pros and cons of on the job training versus off the job training", International Journal of Scientific and Technology Research, vol. 8, no. 10, pp. 671-674.

13. Pavithra, J. \& Ganesan, M. 2016, "A study on awareness and impact of micro-financial schemes", International Journal of Applied Business and Economic Research, vol. 14, no. 8, pp. 5449-5460.

14. Pavithra, J., Dilli Babu, P. \& Ambuli, T.V. 2014, "A study on budgetary control at Maruti Service Masters, Chennai", International Journal of Applied Business and Economic Research, vol. 12, no. 2, pp. 151-161.

15. Gunaraja, T.M. \& Venkatrama Raju, D. 2018, "Determining factors of organisational climate with reference to leadership styles", International Journal of Mechanical Engineering and Technology, vol. 9, no. 9, pp. 1327-1332.

16. Gunaraja, T.M. \& Venkatrama Raju, D. 2018, "The role of job satisfaction and training of employees in determining organisational climate of a selected industry", International Journal of Civil Engineering and Technology, vol. 9, no. 8, pp. 1266-1269.

17. Aarathy, T.S. \& Raju, D.V. 2018, "Performance appraisal and its effects on employees with respect to it sector in Chennai city", International Journal of Civil Engineering and Technology, vol. 9, no. 6, pp. 1535-1538.

18. Aarathy, T.S. \& Raju, D.V. 2018, "Employee perception towards performance appraisal system in IT sector", International Journal of Mechanical Engineering and Technology, vol. 9, no. 5, pp. 131-135.

19. Porselvi, W., Jublee, D. \& Sivanesan, G. 2018, "A study on factors influencing adoption of technology and innovation in banking industry, tamilnadu, India", International Journal of Mechanical Engineering and Technology, vol. 9, no. 5, pp. 789-800.

20. Akessa, G.M. and Dhufera, A.G., 2015. Factors That Influences Students Academic Performance: A Case of Rift Valley University, Jimma, Ethiopia. Journal of Education and Practice, 6(22), pp.55-63.

21. Miller, G. and Shih, C.C., 1999. A faculty assessment of the academic rigor of on-and off-campus courses in agriculture. Journal of Agricultural Education, 40, pp.57-65.

22. Tsinidou, M., Gerogiannis, V. and Fitsilis, P., 2010. Evaluation of the factors that determine quality in higher education: an empirical study. Quality Assurance in education, 18(3), pp.227-244.

23. Farooq, M.S., Chaudhry, A.H., Shafiq, M. and Berhanu, G., 2011. Factors affecting students' quality of academic performance: a case of secondary school level. Journal of quality and technology management, 7(2), pp.1-14.

24. Fitsilis, P., Gerogiannis, V. and Anthopoulos, L., 2014. Ontologies for software project management: a review. Journal of Software Engineering and Applications, 7(13), p.1096.

25. Adams, J.D. and Jaffe, A.B., 1996. Bounding the effects of R\&D: an investigation using matched establishment-firm data(No. w5544). National bureau of economic research

\section{AUTHORS PROFILE}

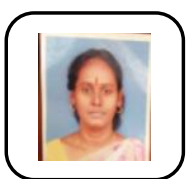

Sumathy arjunan , Assistant Professor Department Of Science and Humanities, Bharath Institution Of Higher Education And Research Tamil Nadu,India

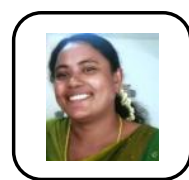

W. Porselvi,, Assistant Professor, Department Of Science and Humanities, Bharath Institution Of Higher Education And Research Tamil Nadu,India

S. Janifer Vinnarasi Assistant Professor,

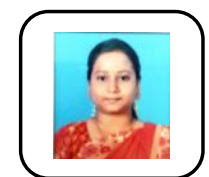

Department Of Science and Humanities, Bharath Institution Of Higher Education And Research Tamil Nadu,India 